\title{
Cross-Cultural Cooperation In The Netherlands: A Damoclian Sword
}

\author{
Coen Heijes, (Email: c.p.a.heijes@rug.nl), University of Groningen, Netherlands
}

\begin{abstract}
The paper studies cross-cultural cooperation between black Curaçaoans and white Dutch in the Netherlands. It shows that while respondents share the same cultural characteristics, the way they handle these and the way they value both their own traits and those of the other group differ with the specific context in which cooperation takes place. Culture is shown to be a more flexible and dynamic concept than is commonly used in the more static approach of standardized, universalistic cultural differences, which still prevail in management thinking on cross-cultural cooperation.
\end{abstract}

"All the world's a stage, and all the men and women merely players. They have their exits and their entrances, and one man in his time plays many parts." (Shakespeare 1598: 42)

\section{INTRODUCTION}

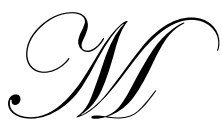

an plays many roles in life. It is something which the great bard William Shakespeare pointed out to us a long time ago. However, it seems to be forgotten wisdom whenever we enter the arena of crosscultural cooperation. Stereotypes, prejudices and standardized cultural differences set the scene and seem to be set in stone. In this paper we address the impact of context on cross-cultural cooperation and the way cross-cultural perception, power, organization and hierarchical position influence cooperation.

The paper is based on ethnographic case-studies on cross-cultural cooperation between black Curaçaoans and white Dutch in the Netherlands in general and focuses in particular on two organizations, the IRS and the police. The general press as well as research so far portray Curaçaoans in stereotypical terms and a negative perception prevails. In this study we focus on the interaction between both groups in the two organizations, using an open approach and examination through participant observation and in-depth interviews. The results show that while respondents share the same cultural characteristics, the way they handle these traits and the way they judge both their own traits and those of the other group differ with the specific context in which the cooperation takes place.

Now, in studies so far on this topic researchers stress cultural and historic factors in explaining the poor social-economic position in the Netherlands of the Curaçaoans (Amesz/Steijle/Vermeulen 1993; Hulst \& Bos 1993; Hulst 1997; Jong, Masson \& Steijlen 1997; San 1998; Gordon 2001; Nolde \& Sera 2001). Culture is a static concept and hangs like a Damoclian sword over Curaçaoan heads, leading them almost inevitably towards unemployment and criminality.

This static approach to culture coincides with a general tendency in research on cross-cultural cooperation and management, which focuses on universal and standardized dimensions along which cultures can be categorized worldwide (Hofstede 1980, 1991; Laurent 1983; Ronen/Shenkar 1985; Tayeb 1988, 1994; Adler 1991; Trompenaars 1993; Schneider \& Barsoux 1997). These approaches and the static concept of culture which underlies it, have rarely been challenged up to this very day resulting in an almost paradigmatic approach which brooks little room for argument (e.g. Søndergaard 1994; Newman/Nollen 1996; Holden 2002; McSweeney 2002; Baskerville 2004; Bing 2004; Fu et al 2004; Triandis 2004; Buck/Sharim 2005; Leung et al 2005; Lu/Lee 2005).

The findings of this study show culture to be a more flexible and dynamic concept and indicate that specific context plays a large role in cross-cultural perception and cooperation. In order to study cross-cultural cooperation, it 
follows that we have to pay specific attention to the actual and specific context that surrounds this cooperation, to the organization, the position in the organization, the social-economic position and the perception of the other and oneself.

This calls for an approach to cross-cultural cooperation in which we use a more dynamic concept of culture which coincides with a more dynamic concept of ethnicity in which we pay special attention to interaction processes and the way ethnicity is employed in the interaction. They are not so much the standard and universalistic cultural differences, which still prevail in thinking on cross-cultural cooperation, that determine the interaction but the 'subjective' cultural differences, which are shown to change dependent on context. In this approach it would be necessary to study the specific context and perception which surrounds the cooperation.

However, the outcome of the research also shows the dynamics to have limits. In spite of the fact that people handle and value their traits differently, they still apply the same characteristics to their specific ethnic group. We find these characteristics to have a firm foundation in processes of history, education and upbringing, language and country of origin. Culture is still a cohesive whole of assumptions which steers our behaviour and over which we have no complete control. Perception is a process that has its origins in this and where we tone down the dynamics of culture, we have to do the same with ethnicity. Ethnicity is all about perception, but this perception is also founded in general historical-cultural processes. For research this means we cannot focus on the interaction alone, but we will also have to study the wider context within which this interaction takes place. The social reality that people create with each other in an interactive process, will lead a life of its own and offer people the framework of their reality.

I will start this paper by describing the methodology, after which I will discuss the migration of Curaçaoans and their position in the Netherlands. I will show how research so far on Curaçaoans in the Netherlands has developed and show the static concept of culture that underlies this. Next I will describe perception and cooperation in two specific case-studies, the IRS and the police. I will round off this paper by discussing the impact of my findings both on the debate on the multicultural society in the Netherlands and on the interrelated concept of culture and ethnicity and the way this influences thinking and research on cross-cultural cooperation in management studies in general.

\section{METHODOLOGY}

In this paper we study cross-cultural cooperation between Dutch and Curaçaoans within different contexts in order to analyze the impact of changing context on perception and cooperation. The two main organizations in which we study cooperation are the IRS and the police. These organizations, which employ persons from both groups, are both large service organizations (more than thirty thousand employees) which may use force to achieve their ends. Both organizations are traditional white male organizations, although they differ in organizational culture, and they have both provided full access to the researcher.

The research has been conducted according to the standards of case study research (Yin 1984; Stewart 1998). Case study is a useful strategy in doing research in a current situation with a strong contextual influence. It requires an approach in which observation, complexity, detailed description and contextuality are important. In studying perception and cooperation within a limited number of organizations, the choice is logical. It provides a depth in data that questionnaires do not readily provide. In this research case study and ethnography, describing another culture, meet, resulting in an ethnographic case-study. Characteristic for the ethnographic case study is that a set of different techniques can be used in collecting data. In this research we use interviews, participant observation and document and literature study.

Now the ethnic background of the interviewer can effect the answers which respondents from a different ethnic background provide, particularly when the subject matter is related to their culture. In addition the language of the interviewer, particularly when it differs from the mother tongue of the respondent, plays a role during the interview (Weeks/Moore 1981; Heelsum 1997; Land 2000). The closer language and culture of the interviewer are to the respondent, the higher the chances of socially acceptable answers. In order to increase the validity of the interviews the researcher makes use of other interviewers as well during the research. These interviewers differ both in gender and in ethnic background from the researcher. All interviewers manage both Dutch and Papiamento, the Curaçaoan language. All interviewers have a firm knowledge of the organizations in which they interview, either from 
past or form present experience. The results of the various interviews have been compared with each other and the results of the various interviewers show no significant differences.

Apart from interviews we have also been able, through the willing cooperation of the organizations, to use participant observation as research method. Because the aim of the research is to analyze and interpret the behaviour of persons within a specific context, this is a useful technique. The respondents were not aware of the fact that they were being monitored for study. As a method for further validating, the member-check has been used. The outcome of the research has been provided to the organizations. This has been done in the form of written reports as well as in the form of workshops, where the members of the organizations are confronted with the outcome and are allowed to discuss it in order to refine it where necessary. Although the paper focuses on the case studies, in our discussion we also employ data from interactive lectures on cross-cultural perception and cooperation between Curaçaoans and Dutch, which were provided to groups of social workers, youth workers and teachers. In addition we make use of other research on the topic. In total two hundred and forty-three persons have been involved in the research, ninety-six by way of interviews, the remainder by way of participant observation over a period of six years, from 1998 till 2004. We use the development research sequence method, employing a rigorous and systematic approach in analyzing data on characteristic and recurrent elements in the perception people have of themselves, the other and cooperation (Spradley 1979, 1980). This way the case study allows to study perception and cooperation between the same ethnic groups in different internal contexts.

\section{CURAÇAOAN MIGRATION AND SOCIAL-ECONOMIC POSITION}

Curaçao is a former colony of the Netherlands in the Caribbean. Currently it is the largest island of the Netherlands Antilles, which forms an autonomous state within the Kingdom of the Netherlands as of 1954, granting it independence apart from matters such as foreign policy, defence, the judicial system and good governance (Statuut 1954). Up to the 1970s migration from Curaçao to the Netherlands was mainly limited to students and the amount of return migration was high. The small community received little attention and perception of Curaçaoans in the Netherlands was generally well (Kroonenburg/Reubsaet 1983; Schuhmacher 1987; Allen/Heijes/Marcha 2003). With the gradual decline of the economic situation on Curaçao, the rising unemployment figures and the departure of Shell from the island, migration to the Netherlands increased in the second half of the 1980s and the number of Curaçaoans in the Netherlands trebled from thirty thousand to ninety thousand in a couple of years. Next to continuing migration of well-educated Curaçaoans, we see a strong increase in the migration of lesser-educed Curaçaoans with a poor familiarity with the Dutch language and culture. Factors such as 'finding a job' or 'better social security' increasingly become motives to migrate (Koot 1979; Allen et al. 2003). Looking for the paradise overseas many unemployed Curaçaoans leave for the Netherlands.

The growing group of poorly-educated Curaçaoans, among which many one-parent families and young people who migrate to the Netherlands without their parents, find it difficult to get a job in the Netherlands. In 1991 thirty percent of the Curaçaoans in the Netherlands is unemployed, as compared to six percent unemployment for the traditional Dutch population. Of the children of parents who migrated to the Netherlands in the early 90s, approximately thirty percent does not finish primary school and forty to fifty percent does not finish secondary school. We may notice a clear split in the Curaçaoan community in the Netherlands, more so than in other communities. On the one hand we find Curaçaoans with poor chances, low education and high unemployment levels, on the other hand we find a group which is educated, employed and fairly successful, particularly compared to other migrated ethnic groups. Opposite the thirty percent drop-out on primary school, we notice for example a fairly high average income and low drop-out scores for children of better-educated Curaçaoans who have migrated twenty years earlier. Although the unemployment figures decrease in the course of the $90 \mathrm{~s}$, this is mainly due to the general economic resurgence in the Netherlands in this period and presently four times as many Curaçaoans are unemployed as compared to the Dutch (SCP 1993; Smeets 1993; CBS 1995; Allen et al. 2003).

\section{STEREOTYPING AND RESEARCH}

The originally positive perception of Curaçaoans in the Netherlands changed towards the end of the 1980s. The perception of the well-educated Curaçaoan turned obsolete and in the 90s perception focused on unemployment, 
marginalisation and criminality (Amesz 1993; Römer 2003; Heijes 2004). Newspapers report increasingly on criminal Curaçaoans and the chief commissioner of police in Amsterdam points his finger specifically at the Curaçaoan group, implying that Curaçao transports its criminals to the Netherlands. The Antillean government reacts furiously, but the chief commissioner is supported by the city council and, indirectly, by the Minister of Justice, who orders an investigation (Nordholt 1993; NRC 1993; BVD 1993).

Irritations and negative perception in the Netherlands coincide with a negative perception of Curaçao itself. When the Dutch Minister of Antillean Affairs travels to Curaçao to sign a treaty on schooling of migrants to the Netherlands, the treaty is recalled at the last moment, resulting in a furious departure of the Dutch Minister (Boxtel 2000). The incident fits the recurring irritations over and across, which find their most recent expression in the debate on drugs smuggling from Curaçao to the Netherlands. Daily numerous Curaçaoans have been smuggling cocaine by plane from Curaçao to the Dutch market. Curaçao points to the hypocrisy of a tolerant Dutch drugs policy and a lack of knowledge of the local Curaçaoan situation. The Netherlands respond by arguing that Curaçao does not take the problem seriously. Curaçao retorts by stating that its prison is largely filled with drugs smugglers, that it spends relatively much funds on law and order and that it is the only country in the Caribbean region that actually checks passengers on drugs on departure. Although Curaçaoan cocaine is only a small part of the total cocaine smuggling to the Netherlands, the media attention is very high. The Antillean Minister of the Netherlands Antilles in The Hague says that the Netherlands tend to point their finger almost reflexively to Curaçao whenever problems get out of hand (Haseth 2002) and representatives of Curaçaoan migrants in the Netherlands criticize the passive attitude of the Netherlands concerning integration of Curaçaoans (Hulst 1997; Schrils 2003). News and perception of Curaçao is continuously negative and coincides with the negative perception of Curaçaoans in the Netherlands (Hulst 1997; Chrino 2001; Heijes 2001a; Verweel 2003; Römer 2003).

Following the turnabout in perception a pallet of research is started on Curaçaoans in the Netherlands, which focuses on criminality, social problems and difficult integration (Amesz et al. 1989; Hulst/Bos 1993; Jong et al. 1997; Hulst 1997; San 1998; Gordon 2001; Nolde/Sera 2001). When we review the research so far, the words of the Antillean poet Cola Debrot come to mind. Words which form a recurring theme in the research and which predestine the fate of Curaçaoans both on Curaçao and in the Netherlands:

Sad isle, sad people

Sad isle in the maelstrom

Of the maelstrom of the maelstrom

Sad isle without a guide. (Debrot 1985: 96)

It is a negative and not very hopeful image that Debrot paints and which we also come across in the research so far. Research rarely addresses social and economic barriers in integration and focuses mainly on cultural factors which are supposed to prevent good communication and cooperation with the Dutch. Alternately they point to the historical relation between the Netherlands and Curaçao, to the failing system of educational and upbringing on Curaçao, to the dichotomy between the mother language on Curaçao, Papiamento, and the Dutch school language, to the way families are structured and the absence of father figures, to the segmentation in society, to the effects of a history of slavery, to the effects of a negative press in the Netherlands, to a culture of 'shame' in which honour is allimportant. Occasionally one aspect is stressed, occasionally another, without however coming to an integrated analysis of all aspects.

Although research focuses on socially-economically weaker groups, research refers to the background of Curaçao and Curaçaoans in general and they are almost inevitably given a victimized role. The general culturalhistorical background is offered as an important dimension and occasionally even as the reason which would explain the backward position of Curaçaoans in the Netherlands. Even though some researchers point out that Curaçaoans in the Netherlands may also be successful, they pay no further attention to this and continue using the general background as an explanation. The relationship between culture and criminality or between culture and poor integration is made rather easily and in a dissertation the two are directly linked, evoking fierce response from Curaçaoans in the Netherlands (San 1998; Janssen 1998; Volkskrant 1998; Resumen 2001; Heijes 2004). The general idea behind the research is clear: 'Sad isle, sad people'. It is an approach in which culture is used as a rather static 
concept, which leaves little room for the dynamics in the concept and for the relation with specific context and perception.

Another remarkable aspect of research so far is that even though it uses the cultural-historical background as a Damoclian sword hanging over Curaçaoan necks, it hardly pays any structural attention to actual perception between Curaçaoans and Dutch. The perception such as we can delineate it from research so far shows a picture of an extremely negative perception of Curaçaoans, both by themselves and by the Dutch. Any positive aspects in selfperception are blithely ignored and the train continues its straight and inevitable dead-end course: 'Sad isle, sad people'. The cultural luggage which Curaçaoans bring along when they migrate from Curaçao to the Netherlands is a given and heavy anchor weighing them inevitably down.

When we compare these findings so far with perception such as it occurs during interactive lectures on crosscultural perception and cooperation between Curaçaoans and Dutch, which were provided to groups of social workers, youth workers and teachers, we encounter a change. In Curaçaoan self-perception (employees of the organizations) we see both negative and positive aspects, such as pride in the own culture, flexibility, relaxed attitude. Curaçaoan perception of the Dutch shows not only criticism but also an acknowledgment of positive traits such as drive and ambition to attain goals. The perception of the Dutch towards their Curaçaoan clients is negative throughout, whereas the self-perception is uniformly positive. In the course of our paper we will study perception an cooperation between Curaçaoans and Dutch in more detail in two specific organizations, The IRS and the police, and see in how far the Damoclian sword affects perception and cooperation in these contexts.

\section{RESULTS}

In analyzing the data from the IRS, the police, interactive lectures on cross-cultural perception and cooperation between Curaçaoans and Dutch and considering the perception such as it appears in other research two things strike us particularly. On the one hand we find that a specific set of aspects recur in all the cases in the perception the respondents have of themselves and of the other. These centre around eight different aspects in which both groups differentiate themselves from each other. The aspects evolve around matters of handling of time, amount of directness, importance of relationships, attitude to work, amount of initiative, decisiveness, emotionality and selfassuredness. In analyzing the cultural differences as they are being perceived by the respondents we find a striking homogeneity across the various cases. There is a high degree of agreement on these cultural dimensions. On the other hand we find that the way respondents value and handle these differences varies and is dependent not only on the specific context in which the cooperation takes place, but also on the position the respondent has in the organization. In studying the IRS and the police in particular we find perception and cooperation to differ both between the two organizations and within the organizations, dependent on the respondent's hierarchical position. Even though the same elements recur every time in the perception of the Curaçaoans on the Dutch and vice versa, we find that the judgment on the perception differs dependent on the specific situation within the organization. In this section we discuss the results, after which we continue by drawing our conclusions in the next section.

\section{THE IRS}

The IRS in the Netherlands employs over 30.000 employees and is structured on a regional basis, with units all over the country which are supervised by the Ministry of Finance. It employs staff all over the spectre incorporating both lowly educated people and academics. The IRS can be typified as a predominantly white male organization. The IRS has taken efforts over the past ten years to create an open and transparent culture in which all employees feel accepted and valuable and are able to criticize and develop their potential. In reality many employees still feel a distrust towards their superiors and in particular towards the higher management echelons. Employees speak of a macho culture in which it is impossible to discuss one's weaknesses. On the other hand we see that employees are mainly satisfied on their direct supervisors, on the safe atmosphere in the team that they actually work in as well as on the work itself and even though unseen barriers for non-Dutch seem to exist in the organization, direct and open discrimination as such is rarely encountered (Personeelsmonitor 1998, 2000, 2002; Eindrapport 2000; Belastingbulletin 2001 Heijes 2004; Heijes/Verweel 2006). 
Within the IRS cooperation is generally perceived as positive from both sides and the higher the position in the organization, the more positive the perception is which the Dutch have of Curaçaoans. From the Dutch point of view this means that Curaçaoans have adapted themselves sufficiently to Dutch aspects. The Dutch continue to notice differences, but they are seen as manageable and in part even positive, such as their "warmth and hospitality". Lower in the organization we see a change in perception. Differences are being seen more sharply and irritation on aspects such as low working-speed, lack of initiative and indirectness increases. Even though the Dutch are aware of the negative perception of Curaçaoans in the media, they find this does not apply to their colleagues. However, the general negative perception is present as a yard-stick on which the behaviour of the Curaçaoans is judged.

All Curaçaoans in the IRS feel they have to exert themselves extra on account of this negative perception and when a Curaçaoan shows deviant behaviour, it is this perception that crops up quickly. Still, Curaçaoans within the IRS indicate that they can manage themselves within the organization by keeping into the account the different "rules of the game of this society". The Dutch are seen as different, but the Curaçaoans find these differences not to be insurmountable and they get irritated by Curaçaoans who do not manage to cope with differences. Lower in the organization we find an increased criticism on the cooperation and Curaçaoans see a lack of respect and consider the adaptation to be one-way: "There is only one adaptation and that is ours. This does not benefit the cooperation." In spite of the criticism, the majority of the Curaçaoans experiences the cooperation as positive.

Within the IRS we find that Curaçaoans perceive the same cultural differences as Curaçaoans elsewehere, but they consider many of the Dutch aspects to be positive, and even more so higher in the organization. All Curaçaoans do, however, find the Dutch to be somewhat too extreme in their aspects. For example, the perception of the 'rude and emotionless Dutchman' is a recurring theme, but within the IRS the perception changes into a positive variant, the 'direct and businesslike Dutchman'. The perception is the same but the interpretation changes, even though they find the Dutch on occasion to be too extreme in this aspect: "You learn to cope, you adjust, but on occasion the Dutchman still is extremely rude." Another example is the importance of rules and regulations. Curaçaoans consider this to be a typical Dutch trait and see it as positive: "Being Dutch is: sticking firmly to patterns and rules. Very planlike. It is wonderful that a Dutchman will always try to keep his appointment. You know what you are up to." At the same time they consider Dutch to be too extreme in this: "An advantage can turn into a disadvantage. Rules are fine, but they tend to be a bit rigid in this." It makes the Dutchman in Curaçaoan eyes less flexible. Another recurring Curaçaoan perception is the positive view the Dutch have of themselves: "They consider themselves the best people of the world." It is this attitude in particular that hinders a positive cooperation, unless the other party is willing and capable to adapt himself sufficiently to the Dutch way.

In their self-perception we see the Curaçaoans within the IRS first and foremost differentiate themselves from Curaçaoans who cause their group to have a bad name in the Netherlands, usually those without a job. In considering one's own culture they differentiate from the Dutch and judge their culture both in positive and negative terms, although they all speak with a sense of pride in having achieved a position in the Dutch society. For example, they acknowledge a lack of directness but do consider themselves to be more tactful than the cold Dutchman, or in their work attitude they will see themselves as hardworking, although they do emphasize that one works to live and that the Dutch are too stressful in their work and enjoy life too little.

\section{THE POLICE}

The police in the Netherlands employ over 40.000 employees and are, with the IRS, one of the largest public organizations in the Netherlands. Like the IRS it is structured on a regional basis and although it has diversity in personnel as far as education is concerned, it can be characterized as a white male organization. Like the IRS it is a monopolist organization serving all citizens, which may use force to perform its tasks. Main differences with the IRS can be seen in the visible, hierarchical structure with clearly separated ranks in the police, the fact that the police encounter more aggression in performing its tasks and a different organizational culture.

Within the organizational culture of the police several terms recur time and again in this as well as in other research: a closed and not very transparent community, loyalty, macho behaviour, gossip culture, hierarchy, distrust of superiors, concern with safety and fear, commitment to the job (Hubers 1992; Elias 1997; Reenen 1997; 
Valkenburg/Weert 1998; Punch/Tieleman/Van den Berg 1999). Loyalty among police employees is strong, particularly on the street and there is a preoccupation with safety: 'Can I or cannot I trust you?' is the underlying thought. Loyalty goes far and to outsiders there is a 'blue wall of silence'. It goes hand in hand with a strong gossip culture within the ranks; forming a part of the group, being accepted within the group is vital if people do not want to be isolated or punished: once you fall outside of the group, rumour spreads fast and you are no longer acceptable. Acceptance of non-white policemen is not easy in this type of organization and we encounter discrimination, harsh jokes, resistance to positive discrimination, strong barriers for integration and many non-white newcomers leave the organization prematurely (Politie 1996; Vries/Houdijk/Vierssen 1997; Vries/Kwee/Waldring 1998; Bovenkerk/an/ Vries 1999).

Within the IRS we see that cooperation, in spite of the differences in perception between both groups, is generally considered to be good. Within the police we find a different situation. The Dutch point out that the Curaçaoans, and more in general colored migrants, attract attention in the organization and fall outside the standard white group. This may lead to discrimination and exclusion. At the same time they consider the situation to be better than some ten, twenty years ago and some speak about a good cooperation. Within the police we see the Dutch differentiate between Curaçaoan colleagues and external contacts with Curaçaoan people. The external perception is very negative; internally the perception is better, although there is a marked difference from the more positive perception within the IRS. The Dutch in the police indicate that Curaçaoans who have adapted are acceptable. However, points of irritation remain and focus on perceived cultural differences, such as for example macho behaviour, low working-tempo and lack of openness and initiative.

The Curaçaoans in the police show the same adaptation as in the IRS. In contrast to the situation in the IRS, this does not always have the desired effect in the police. The Curaçaoan perception on cooperation reveals a wide range of stories about bad cooperation, which often have a poignant character. Many respondents point to the organizational culture as an important factor. Faults of one person are projected on the whole group. The feeling they have to prove themselves comes back in every interview and is stronger within the police than in the IRS. Higher up in the organization the cooperation is seen as better, and Curaçaoans point out that a higher rank in the police results in more respect in the organization.

However, the perception which the Curaçaoans have of the Dutch does not alter with a higher rank and is much more negative than in the IRS. Although the basic cultural differences in their perception of the Dutch do not differ from those in the IRS, they focus much more on discrimination and exclusion. The accents in the perception are on negative aspects such as rudeness, lack of warmth and rigid arrogance. Other, positive aspects such as workingspeed, initiative and keeping one's appointment are recognized, but are snowed under by perception on a lack of respect and bad cooperation.

Although the Curaçaoans clearly differentiate themselves from the Dutch in both organizations, we also find that the respondents indicate they have been 'netherlandized' by their stay and their job in the Netherlands. Both in the police and the IRS we come across aspects such as self-assuredness, directness, working-tempo, meeting one's appointments. In this they do not only differentiate themselves from their fellow countrymen in the Netherlands, they also show a greater appreciation of Dutch aspects without however giving up the pride in their own Curaçaoan background and qualities. They clearly do not see themselves as Dutch and continue to see the cultural differences.

In the self-perception of the Dutch we only see positive aspects and we do not find any change in this selfperception within or across the organizations. The positive self-perception has its pendant in the perception the Curaçaoan have of the Dutch, whom they characterize, in all cases, as a people with a high sense of self-conceit. The only difference between the self-perception in the IRS and the police is that we see in the police a small minority who indicate that the Dutch in the police have firm prejudices, saying at the same time that this doesn't apply to them.

The Dutch perception of Curaçaoans in the police differentiates between external and internal contacts. The external perception is negative. Within the organization this perception is less negative and some indicate that Curaçaoans have adapted sufficiently to be acceptable colleagues. Points of irritation remain and concern aspects such as lack of openness and initiative, macho behaviour, low working-speed and mixing up private and work. On average 
the Dutch perception of Curaçaoans is in the police more negative than in the IRS, which can also be seen in the harsher type of humour we come across in the police.

\section{DISCUSSION}

In this research we explored perception between similar ethnic groups in the Netherlands in changing contexts. We saw general perception of Curaçaoans in the Netherlands deteriorate during the 80 s, hand in hand with a negative perception of Curaçao itself. Media attention is focused on negative aspects, such as violence, school dropouts, unemployment, drugs smuggling and criminality. Research on Curaçaoans focused on the difficult integration of Curaçaoans in Dutch society. Research so far has continuously used the cultural-historical background as an important explanation in explaining the weak social-economic position of Curaçaoans in Dutch society. Culture has turned into an inflexible and unavoidable Damoclian sword. We have found these researchers to base themselves on a static concept of culture, which focuses entirely on negative aspects in perception and does not pay attention on specific context.

When we consider perception we find that social-economic position largely determines the outcome: the selfperception of Curaçaoans is better when their position is better and is worse when their position is worse. Also the perception of the Dutch and Dutch traits is better, when Curaçaoans have a better position in Dutch society, even though all Curaçaoans continue to differentiate themselves clearly from Dutch. In organizations we find that the impact of organizational culture or of a team in which employees feel safe influences the perception processes. Perception and cooperation between Curaçaoans and Dutch depends on the specific organization in which the cooperation takes place, as we may conclude from our research in the IRS and the police, and also depends on the specific position one has in the organizational hierarchy.

Context, perception and cultural differences are so far three mutually dependent aspects which we may encounter in cross-cultural cooperation. Taking perception as a starting-point we find that this results in a series of cultural differences which are perceived by all of the respondents. These differences are firmly rooted in the external context, such as history, education, upbringing and language. Although these differences do not readily fit the standardized universalistic dimensions, such as they are provided by a range of authors (Hofstede 1980, 1991; Laurent 1983; Ronen/Shenkar 1985; Tayeb 1988, 1994; Adler 1991; Trompenaars 1993; Schneider \& Barsoux 1997), we do find a clear stability in these dimensions which we find across the whole range of research. In criticizing universalistic dimensions and the static approach to culture, we do not plead for ignoring cultural differences. One should never throw away the baby with the bathwater. Cultural differences exist and they influence cross-cultural cooperation. And even though they may not be caught in universalistic, standardized dimensions, researchers are able to delineate them through specific ethnographic research. What we should be cautious about is focusing entirely and unilaterally on these cultural differences as they are only a part of the story and tend to ignore specific perception of the cultural differences and context. From our case studies we conclude that the way people handle and value the cultural differences depends on the specific context in which cooperation takes place. We find that similar ethnic groups differ considerably in handling both their self-perception and the perception of the other in different contexts.

Now in the Netherlands we find that perception and cooperation vary with the specific context in which cooperation takes place and the position of power plays a specific role in this. If the hierarchical position of Curaçaoans within an organization is better, cooperation tends to improve between the two groups. This is not so much related to a change in perception on Dutch side, but by a change and increase in flexibility on Curaçaoan side. When we compare the findings of the IRS and the police, we see that perception and cooperation within the police are worse than in the IRS, in spite of an adaptation on Curaçaoan side. Although both organizations are traditionally white male institutions, the police as a whole is a more closed organization in which the importance of uniformity and loyalty are stronger. In addition the external contacts with Curaçaoans are more negative than in the IRS. Where we find that Curaçaoans feel relatively safe in the IRS and its pleasant team environment, we find on the other hand that the specific organizational culture of the police leads to a reduction of feelings of safety and acceptance on Curaçaoan side. In spite of an adaptation on Curaçaoan side, the relation to the Dutch shows an asymmetric element, in which the Dutch on basis of their skin colour and descent have a stronger position of power than Curaçaoans do. 
When we go down the social-economic ladder even further, we find an increasingly worsening perception and cooperation. Low education and a poor social-economic position go hand in hand with a negative change in perception. The position of power a person holds and the asymmetric relationship relates to cooperation and finds its origin in the specific context. They are not just the cultural differences as such which, in conjunction with context and perception, influence cooperation. The specific position of power also plays a role in this and relates to perception and context. Focusing on cultural differences as such ignores these aspects of power which influence cooperation.

In our paper we have discussed the rather static concept of culture that underlies research so far on crosscultural cooperation between Curaçaoans and Dutch in the Netherlands (Amesz et al. 1989; Hulst/Bos 1993; Jong et al. 1997; Hulst 1997; San 1998; Gordon 2001; Nolde/Sera 2001). It is an approach which we may also find in the way cross-cultural cooperation in general is discussed in management literature and has turned into a paradigm for researchers with its focus on universal and standardized dimensions which categorize national cultures all over the world (Hofstede 1980, 1991; Laurent 1983; Ronen/Shenkar 1985; Tayeb 1988, 1994; Adler 1991; Trompenaars 1993; Schneider \& Barsoux 1997; Triandis 2004). The metaphor of this approach to culture is the onion: at its hard core we may find the implicit assumptions, at the outside we encounter the explicit expressions. Implacable and cohesive national cultural dimensions largely determine the way we think and act both consciously and subconsciously and find their origin in long-term processes such as history, language, education and upbringing. Cultures can be easily separated from each other and are considered to be relatively permanent, coherent, homogeneous and pervasive. In research on Curaçaoans in the Netherlands this has resulted in Curaçaoan culture as a Damoclian sword which hangs over Curaçaoan heads and which determines their almost unavoidable descent into unemployment and criminality: 'Sad isle, sad people.'

Our research has shown this approach to present an oversimplified picture of reality. Specific context influences cross-cultural perception and cooperation. The Damoclian sword is not implacable but can be lifted. Culture and in particular the perception and handling of cultural differences is related to the specific context, to the organization in which people work, to their position in the organization and the perception and handling of cultural differences is liable to change. This calls for a different approach to culture and cross-cultural cooperation. The static approach pays too little attention to variations in and between groups and to the impact of specific context on the way people handle and value their culture. It is an approach that coincides with a more dynamic approach of ethnicity in which interaction processes and the way ethnicity is used in these processes plays an important role.

However, we have to tread carefully in this. For one thing, if we draw the dynamics of culture to its ultimate conclusion, culture will turn out to be a meaningless concept, related to the absolute relativism of post-modernists such as Derrida or the historian Hayden White $(1973,1987)$, creating an unworkable situation. Moreover, and more important, in our research we find culture to contain both static and dynamic elements. Even though Curaçaoans are able to handle and value their cultural identity differently in different situations, they do agree on the specific cultural differences which differentiate them from the Dutch. This outcome of the research shows the dynamic concept to have limits. Although people may handle their traits differently, they do apply the same characteristics to their specific ethnic group. Culture is also a durable and cohesive set of assumptions which steers our behaviour and over which we have no complete control. Perception is a process that has its origins in this and where we mitigate the dynamics of culture, we have to do the same with ethnicity.

Ethnicity is generally seen as a perception of a difference in culture or race with which one group differentiates itself from the other group and also as the way these groups handle that difference (Barth 1969; Wallman 1979; Bentley 1987; Stone 1996). Just as in the discussion on the concept of culture, we also find the element of dynamics to be important in the discussion on ethnicity. On the one hand ethnicity is seen as a coherent whole of physical and/or cultural aspects which differentiate one group from the other (Bentley 1987; Stone 1996). It is a static, descriptive definition focusing on objective cultural differences with which one group differentiates itself from the other group. Coherence and unconscious influence play important roles in this approach. Under the influence of Barth (1969) a more dynamic and situational approach to ethnicity has developed which pays close attention to interaction processes and the way ethnicity is employed in those, to the relation between ethnicity and power and to the evolving character of ethnicity. This approach leans strongly on a dynamic concept of culture. However, where we have to be wary of too dynamic an approach to culture, the same holds true for ethnicity. The static approach, 
concentrating on factors such as descent, education and upbringing ignores the dynamics within the concept of culture and the impact of specific context. On the other hand, approaches which stress the dynamic character of ethnicity and stress the situational and fluctuating game of social identity are also a too one-sided approach and ignore the more durable elements in the concept of culture.

For research on cross-cultural cooperation this means we have to focus both on the interaction and on the wider context within which this interaction takes place. The social reality that people create with each other in an interactive process also offers people the framework of their reality. We have to pay attention both to the specific context in which groups find themselves and to their wider cultural patterns and national background. On the one hand culture is a dynamic process and man is able to juggle his cultural balls, dependent on the context; on the other hand culture still forms a coherent whole of basic assumptions, which shape our self-perception and the perception of others. Culture may not be a Damoclian sword but neither is it a hat which can be changed with the occasion. We remain a juggler throwing with balls of culture and ethnicity, but we are also caught up in our own cultural and ethnic ball. We may play many roles, but always against the limited background of the specific stage on which our lives are set. We started our paper with the great bard Shakespeare, and it is no more than fit that we also end our discussion part with him:

"All the world's a stage, and all the men and women merely players. They have their exits and their entrances, and one man in his time plays many parts." (Shakespeare 1598: 42)

\section{LIMITATIONS AND FURTHER RESEARCH}

This research is a multiple ethnographic case-study about cross-cultural cooperation. As such it shares the limitations of case-study research. In our research we have explored cultural differences, perception and cooperation between Curaçaoans and Dutch in the Netherlands and the outcome relates to these specific groups. However, the results of the study and what this means for the concept of culture go beyond the specific case-study and have implications both for cross-cultural cooperation in general.

Within the Netherlands we concluded that research on Curaçaoans so far focused on the difficult integration of Curaçaoans in Dutch society and continuously used the cultural-historical background as an important explanation in explaining their weak social-economic position. In the multicultural debate we also find this in the current situation where discussion has turned into a polarized debate between 'us' and 'them,' which is basically founded on the same static concept of culture (Dijk 1987; Essed 1991;Bolkestein 1991; Schnabel 1998; Scheffer 1999; Contrast 2000; Heijes 2001b). In our research we have seen culture and the way it is handled and valued to be more dynamic and dependent on context. This calls for further research among other ethnic groups in the Netherlands in which researchers take a closer look at the impact of context on cross-cultural perception and cooperation.

Another line of research which directly follows from this paper would focus on cross-cultural cooperation in general. As we saw at the beginning of our paper, management literature on cross-cultural cooperation mainly uses standardized and universalistic dimensions to categorize cultures. The underlying concept of culture such as it is used in research is static, homogeneous, cohesive and pervasive. Our research has shown that, even though cultural differences as such show a stability among similar ethnic groups, the way people handle and value these differences is dependent on the specific context in which people find themselves. This calls for further research on the relation between perception, context and culture. Cross-cultural cooperation is far too complicated a topic to rely on a small number of standardized dimensions. The dynamics of the concept require us to study processes of cross-cultural cooperation not only on a general scale, looking for the general cultural differences between specific ethnic groups, but also on a smaller scale and without losing ourselves in any universalistic illusions. The never-ending game of cross-cultural cooperation has shown itself in these case studies to be far too complex to allow for anything else.

Translations from Dutch or Papiamento (the language on Curaçao) to English were made by the author. 


\section{REFERENCES}

1. Adler, Nancy J. (1991) International Dimensions of Organizational Behavior, Boston: PWS-Kent.

2. Allen, R.M., C. Heijes, and V. Marcha Eds. (2003) Emancipatie en Acceptatie: Curaçao en Curaçaönnaars Beeldvorming en Identiteit Honderveertig Jaar na de Slavernij. Amsterdam: SWP.

3. Amesz, Ineke, Fridus Steijlen, and Hans Vermeulen (1993) Andere Antillianen: Carrières van Laaggeschoolde Antillianen in een Grote Stad. Amsterdam: Het Spinhuis.

4. Barth, Frederik Ed. (1969) Ethnic Groups and Boundaries: The Social Organization of Cultural Differences. London: Allen \& Unwin.

5. Belastingbulletin. Bedrijfsvoering (2001) Waar Gaan wij voor? Arbeidsmotivatie bij de Belastingdienst. Februari 2001.

6. Bentley, G. Carter (1987) Ethnicity and Practice, in Comparative Studies in Society and History 29: 24-55.

7. Bing, John W. (2004) Hofstede's Consequences: The Impact of his Work on Consulting and Business Practices, in Academy of Management Review 181 pp. 80-87.

8. Bolkestein, Frits (1991) Integratie van minderheden moet met lef worden aangepakt, in De Volkskrant, 12-91991.

9. Bovenkerk, F., M. van San, and S. de Vries (1999) Politiewerk in een Multiculturele Samenleving. Apeldoorn: LSOP Politie Onderwijs- en Kenniscentrum.

10. Boxtel, Roger van (2000), in Amigoe 6-12-2000, Algemeen Dagblad 7-12-2000, De Volkskrant 8-12-2000 and Trouw 8-12-2000.

11. BVD Binnenlandse Veiligheidsdienst (1993) Notitie Migratie Antilliaanse Probleemjongeren: Juni 1993. Den Haag: BVD.

12. CBS Centraal Bureau voor de Statistiek (1995 and further), Allochtonen in Nederland. Voorburg/Heerlen: CBS.

13. Chrino (2001) Antilliaans Nieuws met wat meer Balans, in De Volkskrant 29-8-2001.

14. Contrast: Weekblad over de multiculturele samenleving (2000) Allochtonen zijn razend, 7: 27.

15. Dijk, Teun A. van (1987) Communicating Racism. Ethnic Prejudice in Thought and Talk, Newbury Park, CA: Sage.

16. Eindrapport Project Allochtonenbeleid: Communicatie met Belastingplichtigen (2000). Den Haag: Belastingdienst.

17. Elias, Mirjam (1997). Onder Diender: Onstuimig en Beklemmend: De Wereld van de Politie. Amsterdam: Balans.

18. Essed, Philomena (1991) Inzicht in Alledaags Racisme, Utrecht: Het Spectrum B.V.

19. Fu, Ping Ping, Jeff Kennedy, Jasmine Tata, et al (2005) The Impact of Societal Cultural Values and Individual Social Beliefs on the Perceived Effectiveness of Managerial Influence Strategies: A Meso Approach, in Journal of International Business Studies 35 pp. 284-305.

20. Gordon, Irma (2001) Na Kaminda, Op Weg Naar ..... Een Verkennend Onderzoek naar de Relatie tussen de Politie en de Antillianen in Almere. Apeldoorn: Afstudeerscriptie van de Nederlandse Politie Academie.

21. Haseth, C.P. de (2002) Kritiek op Antillen te Makkelijk, in Algemeen Dagblad: Caribische Editie 13-2-2002.

22. Heelsum, A.J. van (1997) De Etnisch-Culturele Positie van de Tweede Generatie Surinamers. Amsterdam: Het Spinhuis.

23. Heijes, Coen (2001a) Nederland en Curaçao: Een Wereld van Verschil, in Algemeen Dagblad 10-2-2001.

24. Heijes, Coen (2001b) Met Andere Ogen: Wonen en Werken in Multicultureel Nederland: Vierentwintig Verhalen. Den Haag: Sdu.

25. Heijes, Coen (2004) Het Stereotype Voorbij: Een Studie naar Onbegrip, Beeldvorming en Samenwerking tussen Curaçaoënaars en Nederlanders in Nederland en op Curaçao. Amsterdam: SWP.

26. Heijes, Coen and Paul Verweel (2006) Diversiteit in Bedrijf: Diversiteitsbeleid in Arbeidsorganisaties: Deel 1: Etnisch Diversiteitbeleid, Medewerkers \& Managers, Amsterdam: SWP.

27. Hofstede, G. (1980/1991) Culture's Consequences: International Differences in Work-Related Values. Beverly Hills: Sage.

28. Holden, Nigel J. (2002) Cross-Cultural Management: A Knowledge Management Perspective. Harlow: Pearson Education Limited.

29. Huberts, L.W.J.C. red. (1992), Bestuurlijke Corruptie en Fraude in Nederland. Arnhem: Gouda Quint. 
30. Hulst, Hans van (1997) Morgen Bloeit het Diabaas: De Antilliaanse Volksklasse in de Nederlandse Samenleving. Amsterdam: Het Spinhuis.

31. Hulst, Hans van and Jeanette Bos (1993) Pan i Respèt: Criminaliteit van Geïmmigreerde Curaçaose Jongeren. Utrecht: Onderzoeksbureau OKU.

32. Janssen, Minka (1998) Stelen en Steken: Een Mislukt Onderzoek naar Criminaliteit onder Curaçaose Jongeren, in Vernieuwing. Tijdschrift voor Onderwijs en Opvoeding 585 pp. 13-14.

33. Jong, W. de, K. Masson, and F. Steijlen (1997) Hoe Doe je je Ding: Antilliaanse Jongeren en Criminaliteit in de Politieregio Rotterdam-Rijnmond. Delft: Eburon.

34. Koot, W. (1979) Emigratie op de Nederlandse Antillen: Een Sociaal-Wetenschappelijk Onderzoek naar Omvang en Achergronden van de Emigratie, in het Bijzonder op Aruba en Curaçao. Muidenberg: Coutinho.

35. Kroonenburg, J. van and T. Reubsaet (1983) Een Verkenning van de Arbeidsmarktsituatie van Antillianen. Nijmegen: Instituut voor toegepaste Sociologie.

36. Land, Hedda van 't (2000) Similar Questions, Different Meanings: Differences in the Meaning of Constructs for Dutch and Moroccan Respondents; Effects of the Ethnicity of the Interviewer and Language of the Interviewing among First and Second Generation Moroccan Respondents. s.1.: s.n..

37. Laurent, Andre (1983) The Cultural Diversity of Western Conceptions of Management, in International Studies of Management \& Organization 13 1-2 pp. 75-96.

38. Leung, Kwok, Rabi S. Bhagat, Nancy R. Buchan, Miriam Erez, and Christina B. Ginson (2005) Culture and International Business: Recent Advances and their Implications for Future Research, in Journal of International Business Studies 36 pp. 357-378.

39. Lu, Lung-Tan and Yuan-Ho Lee (2005) The Effect of Culture on the Management Style and performance of International Joint Ventures in China: The Perspective of Foreign Parents, in International Journal of Management 223 pp. 452-462.

40. McSweeney, Brendan (2002) Hofstede's Model of National Cultural Differences and their Consequences: A Triumph of Faith - A Failure of Analysis, in Human Relations 551 pp. 89-118.

41. Newman, Karen L. and Stanley D. Nollen (1996) Culture and Congruence: The Fit between Management Practices and National Culture, in Journal of International Business Studies 274 pp. 753-779.

42. Nolde, E. and M. Sera (2001) Antilliaanse Jongeren in Detentie: Een Nadere Kennismaking met de Jonge Antilliaan in Nederland. Groningen : Hanzehogeschool Groningen.

43. Nordholt, E.E. (1993) Als Ik het Niet Zeg, Wie Zegt het dan Wel?: Commissaris Nordholt over Allochtone Criminaliteit, in NRC Handelsblad 3-2-1993 and Curaçao Loost Criminelen naar Nederland, in Trouw 13-21993.

44. NRC Handelsblad (1993) Antillen Verborgen over Nederland and 'Antillen Betrokken bij "Lozen" Jongeren', in NRC Handelsblad 17-2-1993 and 19-2-1993.

45. Personeelsmonitor: Rapport Belastingdienst (1998, 2000, 2002). Den Haag: Belastingdienst.

46. Politie en diversiteit 1996-2000 (1996). Den Haag: Ministerie van Binnenlandse Zaken, directie Politie.

47. Punch, M., P. Tieleman, and A.H. van den Berg (1999). 'Politiecultuur', in C.J.C.F. Fijnaut, E.R. Muller and U. Rosenthal Eds. (1999) Politie: Studies over haar Werking en Organisatie. Alphen aan de Rijn: Samsom.

48. Reenen, P. van (1997). Police Integrity and Police Loyalty: The Stalker ilemma, in Policing and Society december 1997 pp. 1-45.

49. Resumen (2001) Marion van San Kousanda Problema Grave Atrobe 1/8-12-2001.

50. Reubsaet, T.J.M. and J.A. Kropman (1986) Beter Opgeleide Antillianen op de Arbeidsmarkt. Nijmegen: Instituut voor Toegepaste Sociale Wetenschappen.

51. Römer, Beeldvorming en Politiek: Een Diachronische Analyse, in Allen, R.M., C. Heijes \& V. Marcha ed. (2003) Emancipatie en Acceptatie: Curaçao en Curaçaoënaars Beeldvorming en Identiteit Honderveertig Jaar na de Slavernij. Amsterdam: SWP.

52. Ronen, Simcha and Oded Shenkar (1985), Clustering Countries on Attitudinal Dimensions: A Review and a Synthesis, in Academy of Management Review 103 pp. 434-454.

53. San, M. van (1998) Stelen en Steken: Delinquent gedrag van Curaçaose Jongeren in Nederland. Amsterdam: Het Spinhuis.

54. Scheffer, Paul (2000) Het multiculturele drama, in NRC Handelsblad, 29-1-2000.

55. Schnabel, Paul (1991) De Multiculturele Illusie: Een Pleidooi voor Aanpassing en Assimilatie, Utrecht: Forum. 
56. Schneider, Susan C. and Jean-Louis Barsoux (1997) Managing Across Cultures. London: Prentice Hall.

57. Schrils, James (2003) Onze Politieke Mentaliteit: Een gevaar voor de Democratie, in Allen, R.M., C. Heijes \& V. Marcha ed. (2003) Emancipatie en Acceptatie: Curaçao en Curaçaoënaars Beeldvorming en Identiteit Honderveertig Jaar na de Slavernij. Amsterdam: SWP.

58. Schuhmacher, P. (1987) De Minderheden: 700.000 Migranten Minder Gelijk. Amsterdam: Van Gennep.

59. Shakespeare, William (1598) As You Like It, in Louis B. Wright and Virginia A. Lamar ed. (1959) The Folger Library General Reader's Shakespeare As You Like It. New York: Washington Square Press.

60. SCP Sociaal en Cultureel Planbureau (1993 and further) Rapportage Minderheden 1993 and further. Rijswijk: CSP.

61. Smeets, H.M.A.G. (1993 and further) Jaarboek Minderheden 1993 and further. Houten: Bohn, Stafleu Van Loghum.

62. Søndergaard, Mikael (1994) 'Research Note: Hofstede's Consequences: A Study of Reviews, Citations and Replications', in Organization Studies 153 pp. 447-456.

63. Spradley, James P. (1979) The Ethnographic Interview. New York: Holt, Rinehart and Winton.

64. Spradley, James P. (1980) Participant Observation. New York: Holt, Rinehart and Winton.

65. Statuut voor het Koninkrijk der Nederlanden (1954), Rijkswet van 28 Oktober 1954 Stb. 503 Houdende Aanvaarding van een Statuur voor het Koninkrijk der Nederlanden. Den Haag: Sdu.

66. Stewart, Alex (1998) The Ethnographer's Method, Sage: London.

67. Stone, John (1996) Ethnicity, in Adam Kuper and Jessica Kuper Eds. (1996) The Social Science Encyclopedia: Second Edition. London: Routledge.

68. Tayeb, Monir H. (1988) Organizations and National Culture: A Comparative Analysis. London: Sage.

69. Tayeb, Monir H. (1994) Organizations and National Culture: Methodology Revisited, in Organization Studies 15 pp. 429-446.

70. Triandis, Harry C. (2004) The Many Dimensions of Culture, in Academy of Management Review 181 pp. 8893.

71. Trompenaars, Fons (1993) Riding the Waves of Culture: Understanding Cultural Diversity in Business. London: Nicholas Brealey.

72. Valkenburg, W.E.C.A. and A.A.G.J.M. Weert red. (1998). Corruptie: Verschijningsvormen, Opsporing, Bestrijding en Voorkoming. Lelystad: Koninklijke Vermande.

73. Verweel, Paul (2003) Double Dutch: De Europese en Curaçaos-Antilliaanse Bestuursstijl, in Allen, R.M., C. Heijes \& V. Marcha ed. (2003) Emancipatie en Acceptatie: Curaçao en Curaçaoënaars Beeldvorming en Identiteit Honderveertig Jaar na de Slavernij. Amsterdam: SWP.

74. Volkskrant, De (1998) Antillianen Krijgen Soms Al Vroeg een Mes Kado 5-9-1998 and Opboksen Tegen de Consumptiecultuur 19-9-1998.

75. Vries, Sjiera de, Damiette Houdijk, and Dirk van Vierssen (1997) Acceptatie van Allochtone Agenten: Een Onderzoek naar Factoren die Acceptatie Bevorderen en Bemoeilijken. Leiden: Rijksuniversiteit Leiden.

76. Vries, Sjiera de, Juliette Kwee, and Ismintha Waldring (1998). Uitstroom van Allochtonen uit de Executieve Politiedienst. Leiden: Vakgroep sociale en organisatiepsychologie, Rijksuniversiteit Leiden.

77. Wallman, Sandra Ed. (1979) Ethniciy at Work. London: Macmillan.

78. Weeks, Michael F. and R. Paul Moore (1981) Ethnicity-of-Interviewer Effects on Ethnic Respondents, in The Public Opinion Quarterly 452 pp. 245-249.

79. White, H. (1973) Metahistory: The Historical Imagination in Nineteenth-Century Europe. Baltimore: The Johns Hopkins University Press.

80. White, H. (1987) The Content of the Form: Narrative Discourse and Historical Representation. Baltimore: The Johns Hopkins University Press.

81. Yin, Robert K. (1984) Case Study Research: Design and Methods. London: Sage. 


\section{NOTES}

